\title{
Stopping circulatory vaccine-derived poliovirus in Kaduna state by scaling up special interventions in local government areas along rivers of interest- kamacha basin experience, 2013-2015
}

Audu I. Musa ${ }^{1 *}$, Faisal Shuaib², Fiona Braka ${ }^{1}$, Pascal Mkanda ${ }^{1}$, Richard Banda', Charles Korir ${ }^{1}$, Sisay G. Tegegne ${ }^{1}$, Suleiman Abdullahi', Gregory C. Umeh', Terna I. Nomhwange', Hadiza Aliyu lyal', Sambo Ishaku', Usman Adamu², Eunice Damisa², Murtala Bagana², Victor Gugong ${ }^{3}$, Hadiza Balarabe ${ }^{4}$, Peter Nsubuga ${ }^{5}$ and Rui G. Vaz ${ }^{1}$

\begin{abstract}
Background: The Kamacha river is one of the five polio environmental surveillance sites in Kaduna State where 13 circulating vaccine-derived polioviruses (cVDPDs) were isolated between 2014 and 2015. Kamacha river accounted for 5 of all reported cVDPVs in Kaduna State between 2014 and 2015. Poor quality Supplemental Immunization Activities (SIAs) and low population immunity have been reported in the 10 LGAs with tributaries that flow into the river. We described the processes of implementing the various health interventions in these targeted LGAs along the Kamacha River and assessed the effectiveness of the interventions in stopping CVDPV in Kaduna, state, Nigeria.

Methods: Special interventions that had been proven to be functional and effective in reaching unreached children with potent vaccines in the state were scaled up in these targeted 10 LGAs along the Kamacha River. These interventions included revision of house based microplans, scaling up of transit vaccination, scaling up of youth engagement, intensified supportive supervision, scaling up of Directly Observed Polio Vaccination (DOPV) and in-between rounds vaccination activities. We analyzed immunization plus days (IPDs) administrative tally sheet and monitoring data from 10 rounds before and 10 rounds after the special interventions.
\end{abstract}

Results: The number of children immunized increased from 1,862,958 in December 2014 before the intervention to 1,922,940 in March 2016 after the intervention.

Lot Quality Assurance Sampling (LQAS) results showed an increase in the proportion of LGAs accepted at coverage $>90 \%$ after the interventions, from $67 \%$ before intervention to $84 \%$ after intervention. The proportion of non-polio AFP children with $>4$ doses of oral polio vaccine increased from 2 to $8 \%$ before to $93-98 \%$ after the interventions.. No new environmental cVDPV has been isolated since the introduction of the interventions in April 2015 until July 2016.

Conclusion: Scaling up known working interventions in the 10 LGAs with tributaries that drain to Kamacha River environmental sample site may have contributed to improved immunity and interruption of cVDPV in Kaduna state. These interventions should be replicated in LGAs and states with persistent poliovirus isolation.

Keywords: Circulatory vaccine derived polio-virus, Special interventions, Nigeria

* Correspondence: musaau@who.int

${ }^{1}$ World Health Organization, Abuja, Nigeria

Full list of author information is available at the end of the article

(c) The Author(s). 2018 Open Access This article is distributed under the terms of the Creative Commons Attribution 4.0 International License (http://creativecommons.org/licenses/by/4.0/) which permits unrestricted use, distribution, and reproduction in any medium, provided you give appropriate credit to the original author(s) and the source, provide a link to the Creative Commons license, and indicate if changes were made. The Creative Commons Public Domain Dedication waiver (http://creativecommons.org/publicdomain/zero/1.0/) applies to the data made available in this article, unless otherwise stated. 


\section{Background}

As progress towards wild poliovirus eradication accelerated in the late 1990s, new risks to a polio-free world became apparent. Vaccine-derived polioviruses (VDPVs) can both circulate and paralyze, causing polio outbreaks due to circulating VDPVs (cVDPVs).Immune vaccine-derived polioviruses (iVDPVs) may cause paralysis in some individuals with primary immunodeficiency [1-5]. In May 2008, in line with guidance from the World Health Organization (WHO)'s Scientific Advisory Group of Experts on immunization (SAGE), the World Health Assembly (WHA) endorsed the principle of synchronized oral polio vaccine (OPV) cessation globally, to reduce the incidence of cVDPV [6].

To strengthen surveillance for polioviruses, the WHO recommends complementary surveillance by introducing environmental surveillance [7, 8]. As fewer wild poliovirus (WPVs) are detected, the role of environmental sampling will increase; in addition to its use for detection of potential VDPVs. Nigeria introduced environmental surveillance in 2011 in Kano State, and it was expanded to Kaduna State in 2013 starting with three sites of Rigassa River in Igabi, Limanchi Kona Bridge, and Kamacha River in Sabon Gari, and Zaria local government areas (LGAs). The two other sites of Kusfa Bridge and Ungwan Jaba of Zaria and Sabon Gari LGAs were added in 2015 to increase sensitivity. Despite several rounds of polio supplemental immunization activities (SIAs), there remained sanctuaries with the persistent transmission of cVDPV in Kaduna State [4, 8, 9]. A total of five cVDPV2 from AFP were isolated in 2013, 30 in 2014 and one in 2015 (10). Nigeria contributed 41\% of cVDPVs in Africa between 2012 and 2016 and $23 \%$ of the cases in Nigeria were from Kaduna State [10]. A total of $13 \mathrm{cVDPVs}$ were isolated from the environment in 2014 and 2015 of which 11 (84.6\%) were from Kamacha River site in Zaria LGA and the remaining $15.4 \%$ from Limanchi Kona Bridge site in Zaria and Rigassa River site in Igabi LGA [11, 12].

Supplemntal Immunization Activities, monitoring data and supervision report showed poor quality SIAs and potential low population immunity in the LGAs along this river. The root causes ranged from persistent poor team performance by vaccination team members, refusal of immunization by caregivers, and poor micro-planning, and a high number of unimmunized children from poor routine immunization coverage [13-16].

To address low population immunity and poor vaccination team performance, special interventions that were proven to be functional and effective in the state were scaled up in these targeted 10 LGAs along the Kamacha River. These interventions included revision of household based micro plans (involved listing of all major and minor settlements and enumeration of all under- 5 years old children), scaling up of transit vaccination (for examples motor parks, check points, markets vaccinations), scaling up of youth engagement as well as intensified supportive supervision (youth accompanied vaccination teams working in volatile or security compromised settlements). Others were scaling up of Directly Observed Polio Vaccination (DOPV) (immunization outside the households two to 3 days before the vaccination teams commence house-to-house vaccination) and in-between rounds vaccination activities (vaccination immediately after a campaign targeted at under-performing settlements) [17-19].

We described the processes of implementing the various health interventions in the 10 targeted LGAs along the Kamacha River and assessed the effectiveness of the interventions in stopping cVDPV, Kaduna state, Nigeria.

\section{Methods}

\section{Targeted area}

We targeted the 10 LGAs with tributaries to Kamacha River in Zaria LGA. The 10 LGAs were Zaria, Sabon Gari, Kudan, Giwa, Soba, Kubau, Makarfi, Ikara, Birnin Gwari and Igabi. Tributaries of rivers from 10 LGAs in Kaduna State drained into Kamacha River in Zaria (Fig. 1). Tributaries from Sabuwa and Danja LGAs of Katsina passed through Birnin Gwari, Igabi and Kudan LGA to drain to Kamacha while another tributary from Makarfi LGA passed through Kudan, Giwa and Sabon Gari LGAs to drain into the Kamacha River. The last route was from Bauchi state through Kubau, Ikara and Soba LGAs to the Kamacha River.

\section{Study design}

We implemented six special interventions in the 10 LGAs in addition to the routine activities that were being conducted during SIAs (Table 1). We implemented the special interventions in phases from pre-campaign, intra-campaign, and post-campaign for each polio SIA. We evaluated the impact of the interventions by assessing the proportion of LGAs with LQAS accepted at coverage $\geq 90 \%$ by polio vaccination activities before and after the special interventions in the 10 LGAs with tributaries to Kamacha River.

\section{Interventions}

We conducted the following interventions: household based micro plans (involved listing of all major and minor settlements and enumeration of all $<5$ years old children), scaling up of transit vaccination (for examples motor parks, check points, markets vaccinations), scaling up of youth engagement as well as intensified supportive supervision (youth accompanied vaccination teams working in volatile or security compromised settlements). Others were scaling up of Directly Observed 


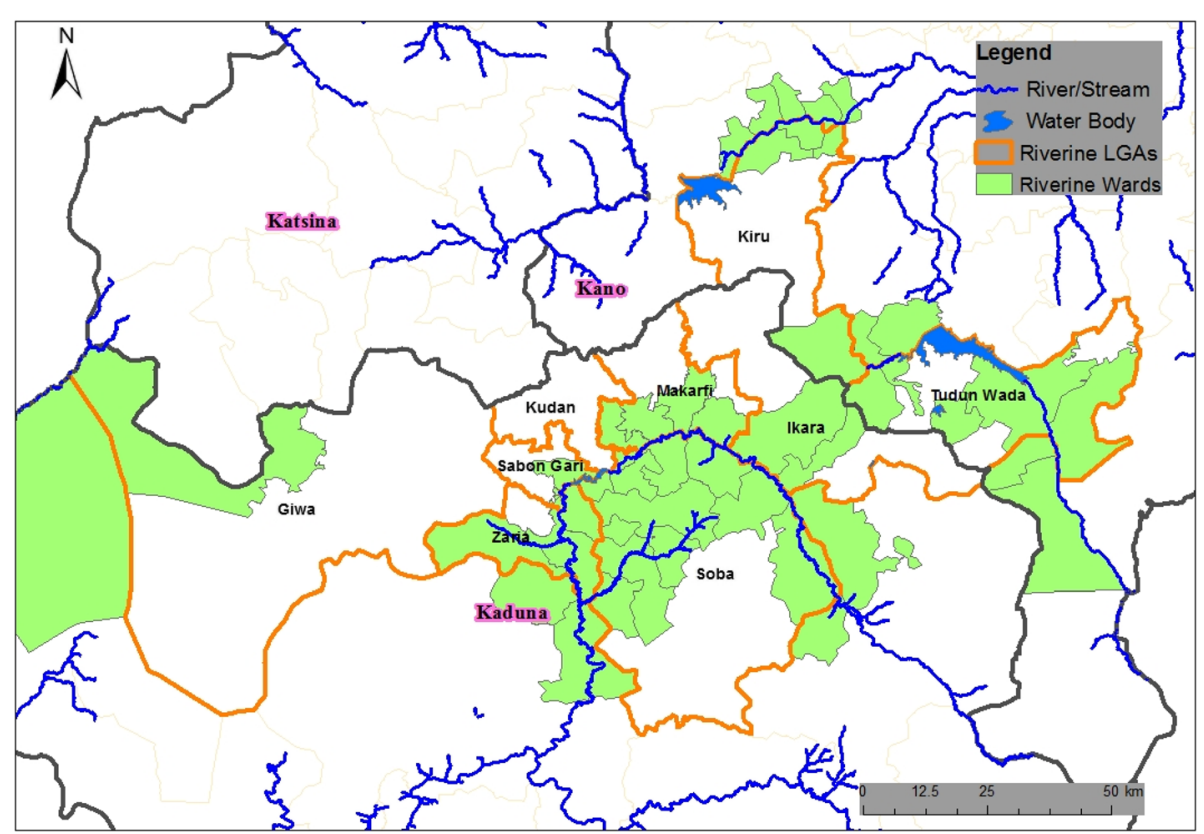

Fig. 1 Map showing tributaries from 10 LGAs in Kaduna state that drain into to river Kamacha, April 2015

Polio Vaccination (DOPV) (immunization outside the households two to 3 days before the vaccination teams commence house-to-house vaccination) and in-between rounds vaccination activities (vaccination immediately after a campaign targeted at under-performing settlements) (Table 1 \& 2).

\section{Pre-campaign}

The major special intervention implemented at this phase was improved micro planning. We conducted community participative physical walk-through and micro-census in the catchment areas and settlements
$1000 \mathrm{~m}$ from the course of the rivers. The process involved enumeration of the total number of households and eligible children $<5$ and $<1$ year of age in all the households in the catchment settlements. The plans were used for SIAs, routine immunization and in-between rounds vaccination activities.

\section{Intra-campaign}

Special interventions implemented at this phase included expanded Directly Observed Polio Vaccination (DOPV), youth engagement for vaccination, transit points' vaccination, and in-between round activities.

Table 1 Description of special interventions conducted in the 10 local government areas with tributaries to the Kamacha RiverKaduna, Nigeria, 2014-2016

\begin{tabular}{|c|c|c|c|}
\hline Intervention & Description & $\begin{array}{l}\text { Where it was used } \\
\text { before in Nigeria }\end{array}$ & $\begin{array}{l}\text { When we started using } \\
\text { it in Kamacha }\end{array}$ \\
\hline $\begin{array}{l}\text { 1) Walk-through } \\
\text { Micro plans }\end{array}$ & $\begin{array}{l}\text { Enumeration and line-listing of households } \\
\text { and children }<5 \text { years and }<1 \text { year of age in each them. }\end{array}$ & $\begin{array}{l}\text { Kano state in } \\
\text { September } 2013\end{array}$ & April 2015 \\
\hline 2) DOPV & $\begin{array}{l}\text { Directly observed outside OPV vaccination of children. } \\
\text { It was used exclusively for the first } 2-3 \text { days of each } \\
\text { round of OPV vaccination }\end{array}$ & $\begin{array}{l}\text { Bauchi and Kano, in } \\
\text { year in August } 2014\end{array}$ & $\begin{array}{l}\text { Introduced to Kamacha LGAs } \\
\text { in September } 2014 \text { and scaled } \\
\text { up in April } 2015\end{array}$ \\
\hline $\begin{array}{l}\text { 3) Youth } \\
\text { engagement }\end{array}$ & $\begin{array}{l}\text { Youth engaged in wards and settlements with high } \\
\text { resistant of polio vaccination and Vaccination } \\
\text { team harassment }\end{array}$ & $\begin{array}{l}\text { Rigassa in Igabi LGA } \\
\text { Kaduna state from } \\
\text { May } 2014\end{array}$ & $\begin{array}{l}\text { Introduced to Kamacha LGAs } \\
\text { in September } 2014 \text { and scaled } \\
\text { up in April } 2015\end{array}$ \\
\hline $\begin{array}{l}\text { 4) Transit points } \\
\text { vaccination }\end{array}$ & Vaccination in motor parks, roads blocks and markets & Borno, Yobe, and Taraba & $\begin{array}{l}\text { Introduced to Kamacha LGAs in } \\
\text { September } 2014 \text { and scaled } \\
\text { up in April } 2015\end{array}$ \\
\hline $\begin{array}{l}\text { 5) In-between } \\
\text { rounds Vaccination }\end{array}$ & $\begin{array}{l}\text { Vaccination in settlements with high missed children } \\
\text { during SIAs or settlements with potential immunity gaps. }\end{array}$ & Borno, Yobe in 2013 & April 2015 \\
\hline $\begin{array}{l}\text { 6) Engagement of } \\
\text { Independent monitors }\end{array}$ & Monitor implementation of planned activities (in-process) & Kaduna \& other states & April 2015 \\
\hline
\end{tabular}


Table 2 Special interventions introduced in the 10 local government areas with tributaries to the Kamacha River- Kaduna, Nigeria, 2014-2016

\begin{tabular}{lll}
\hline Intervention & Before Scaling UP & After Scaling UP \\
\hline No of Independent Monitors (in-process) & 40 & 96 \\
No Youth Engagement & 120 & 338 \\
No of Transit Points for Vaccination & 4 & 32 \\
Revised Household Based Microplan (no of LGAs) & 0 & 3 \\
DOPV Activities & & 3 \\
$\quad$ No of DOPV Days & 2 & 2407 \\
No of DOPV Teams & 1270 & 2294 \\
No of DOPV Supervisors & 423 & 1 \\
\hline In Between Round Activities with New Attractive Pluses Added (Nodules) & 0 & \\
\hline
\end{tabular}

Furthermore, we introduced intra-campaign mock lot quality assurance sampling (LQAS) surveys in these priority LGAs conducted on day 3 and day 4 of polio SIAs to assess the coverage in wards and settlements already completed during the exercise. The trained LQAS surveyors were deployed to sample 60 households per day per LGA for the 2 days. The results were presented at the daily evening review meetings to the LGA team to initiate immediate plans for revisits or take other necessary actions to vaccinate the missed children and correct poor performing teams.

\section{Post-campaign and in-between rounds}

At the end of each round of vaccination, we prioritized settlements with a record of a high number of missed children or poor access during the SIA for in-between rounds activities. The State Emergency Operations Center (EOC) organized a 1-day feedback session with the various stakeholders to discuss issues and challenges during the vaccination rounds. The wards and settlements with a high proportion of missed children or with potential immunity gaps were targeted for in-between rounds vaccination using the various strategies mentioned before.

\section{Primary outcomes}

The primary outcomes were children immunized by the transit and DOPV teams during SIAs and by the in-between round teams after SIAs; number of cVDPV isolated after the interventions and the number of OPV doses received by children with non-polio associated paralysis.

\section{Data collection}

We collected data from the vaccination teams' tally sheets, weekly surveillance, laboratory results on OPV doses of non-polio associated paralysis, and cVDPV isolation and Lots Quality Assurance Sampling (LQAS).

\section{Data analysis}

We analyzed the number of children immunized by polio vaccination teams during SIAs and in-between rounds activities; trend in the number of oral polio vaccine doses received by children with non-polio associated acute flaccid paralysis; and trend of cVDPV before and after the special interventions in the 10 LGAs with rivers that drained to Kamacha river.

We also analyzed the proportion of LGAs with LQAS accepted at coverage $\geq 90 \%$ by polio vaccination activities before and after the special interventions in the 10 LGAs with tributaries to Kamacha River. We used IPDs data from March, April, May, June, August, September, November to December of 2014, and January and March of 2015 compared with April, June, July, August, September, October to December of 2015, and January, February, and March of 2016.

\section{Results}

Data from tally sheets showed more children vaccinated in each round of polio vaccination after the intervention. There was an increase from the highest immunized before the intervention of 1,862,958 in December 2014 to the highest immunized after the intervention of 1,922,940 in March 2016 (Table 3 \& 4).

Lots Quality Assurance Sampling results showed an increase in the proportion of LGAs accepted at coverage $>90 \%$ after the intervention. The proportion of the LGAs accepted at coverage $>90 \%$ was higher in 7 of the 10 IPDs rounds after the intervention while the proportion of the LGAs accepted at coverage > 90\% was higher in three IPDs rounds before the intervention (Table 5).

Ninety percent of the children with non-polio associated acute flaccid paralysis had four or more OPV doses after the intervention (Table 6).

There was an increase in the number of vaccinated children (by tally sheet) from DOPV in all the IPDs rounds after scaling up the intervention (Fig. 2). In most of the rounds $>80 \%$ of the target children were 
Table 3 Children immunized by special interventions during in-between rounds activities in the 10 local government areas with tributaries to the Kamacha River- Kaduna, Nigeria, 2014-2016

\begin{tabular}{lllllll}
\hline Intervention & Qtr2 2015 & Qtr3 2015 & Qtr4 2015 & Qtr1 2016 & Qtr2 2016 & Sub Total \\
\hline Market Vaccination & 85,194 & 93,318 & 108,270 & 254,633 & $4,311,815$ & 973,230 \\
Motor Park Vaccination & 123,604 & 122,560 & 135,093 & 149,988 & 49,967 & 580,212 \\
FRSC Check Point Vaccination & 12,110 & 19,115 & 143,293 & 24,121 & 11,413 & 81,052 \\
Youth DOPV vaccination & 73,894 & 57,443 & 79,791 & 193,564 & 405,648 & 810,340 \\
Permanent Hospital vaccination & 28,217 & 28,670 & 40,030 & 121,087 & 149,737 & 367,741 \\
Cross Border Vaccination & 14,845 & 17,608 & 14,166 & 21,180 & 13,340 & 81,139 \\
Nomadic Route vaccination & & & 9558 & 18,339 & 36,723 & 64,620 \\
Hit and Run vaccination & & & & & 17,487 & 17,487 \\
Total & 336,864 & 338,714 & 401,201 & 782,912 & $1,16,130$ & $2,975,821$ \\
\hline
\end{tabular}

vaccinated through DOPV, the highest were in rounds two and five (June and September 2015). The highest contribution of DOPV before the scaling up was $70 \%$ in the month of January 2015.

The trend of environmental sample results from Nigeria weekly polio statistics showed no new environmental cVDPV isolated after the introduction of the interventions in April 2015 (Fig. 3). The last virus isolated in the state was in week 10 of 2015.

\section{Discussion}

We found that scaling up the six interventions that were known to work in the 10 LGAs with tributaries that drain to Kamacha River environmental sample site, may have contributed to improved immunity and interruption of cVDPV in the state. Human and financial resources were targeted to the areas with known gaps rather than generalizing the utilization of the resources with little effect.

Table 4 Number of children immunized by Polio vaccination activities (tally sheet data) before and after the special interventions in the 10 local government areas with tributaries to the Kamacha River - Kaduna, Nigeria, 2014-2016

\begin{tabular}{lll}
\hline IPDs Round & Before Intervention & After Intervention \\
\hline Round 1 & $1,703,166$ & $1,841,964$ \\
Round 2 & $1,656,280$ & $1,872,952$ \\
Round 3 & $1,720,446$ & $1,839,950$ \\
Round 4 & $1,715,668$ & $1,880,567$ \\
Round 5 & $1,743,582$ & $1,754,820$ \\
Round 6 & $1,782,709$ & $1,764,809$ \\
Round 7 & $1,840,821$ & $1,902,968$ \\
Round 8 & $1,862,958$ & $1,906,804$ \\
Round 9 & $1,881,866$ & $1,916,276$ \\
Round 10 & $1,829,370$ & $1,922,940$ \\
\hline
\end{tabular}

We also found that introduction of the multiple working interventions in settlements with noncompliance improved the quality of household based micro plans and intra-campaign monitoring. These interventions resulted in reaching more children during polio SIAs with a reduction in missed children due to noncompliance and child absence [20, 21].

Furthermore, we found that scaling up of validated vaccination, just as in tuberculosis treatment using directly observed treatment short course (DOTS) accelerated the process of improving population immunity in the noncompliance community. It ensured vaccination team members do not connive with caregivers from non-compliant households to finger mark the children without actually vaccinating them with OPV during polio SIAs [19].

The study also revealed the value of vaccinating children in special places as nomadic routes and security compromised settlements. Despite the low number of children vaccinated in these special areas, they are highly valued children, who are sometimes

Table 5 Proportion of LGAs with LQAs accepted at coverage $\geq 90 \%$ by Polio vaccination activities before and after the special interventions in the 10 Local Government Areas with tributaries to Kamacha River- Kaduna, Nigeria, 2014-2016

\begin{tabular}{lll}
\hline IPDs Round & Before Intervention (\%) & After Intervention (\%) \\
\hline Round 1 & 18 & 61 \\
Round 2 & 35 & 56 \\
Round 3 & 50 & 78 \\
Round 4 & 76 & 78 \\
Round 5 & 94 & 71 \\
Round 6 & 80 & 71 \\
Round 7 & 71 & 61 \\
Round 8 & 72 & 80 \\
Round 9 & 67 & 90 \\
Round 10 & 67 & 84 \\
\hline
\end{tabular}


Table 6 Trend in the number of Oral Polio Vaccine Doses Received by children with Non-Polio Associated Acute Flaccid Paralysis (NPAFP) in the 10 Local Government Areas with tributaries to Kamacha River- Kaduna, Nigeria, 2014-2016

\begin{tabular}{|c|c|c|c|c|c|c|c|c|c|c|c|c|}
\hline \multirow[t]{2}{*}{ LGA } & \multicolumn{3}{|l|}{2013} & \multicolumn{3}{|l|}{2014} & \multicolumn{3}{|l|}{2015} & \multicolumn{3}{|l|}{2016} \\
\hline & $\begin{array}{l}0 \text { Doses } \\
(\%)\end{array}$ & $\begin{array}{l}1-3 \text { Doses } \\
(\%)\end{array}$ & $\begin{array}{l}>4 \text { Doses } \\
(\%)\end{array}$ & $\begin{array}{l}0 \text { Doses } \\
(\%)\end{array}$ & $\begin{array}{l}1-3 \text { Doses } \\
(\%)\end{array}$ & $\begin{array}{l}>4 \text { Doses } \\
(\%)\end{array}$ & $\begin{array}{l}0 \text { Doses } \\
(\%)\end{array}$ & $\begin{array}{l}1-3 \text { Doses } \\
(\%)\end{array}$ & $\begin{array}{l}>4 \text { Doses } \\
(\%)\end{array}$ & $\begin{array}{l}0 \text { Doses } \\
(\%)\end{array}$ & $\begin{array}{l}\text { 1-3 Doses } \\
(\%)\end{array}$ & $\begin{array}{l}>4 \text { Doses } \\
(\%)\end{array}$ \\
\hline Birnin Gwari & 10 & 0 & 90 & 0 & 0 & 100 & 0 & 8 & 92 & 0 & 8 & 92 \\
\hline Giwa & 0 & 8 & 92 & 0 & 7 & 93 & 0 & 5 & 93 & 0 & 0 & 100 \\
\hline Igabi & 0 & 32 & 68 & 0 & 10 & 90 & 0 & 8 & 92 & 0 & 5 & 95 \\
\hline Ikara & 0 & 0 & 100 & 0 & 5 & 95 & 0 & 0 & 100 & 0 & 0 & 100 \\
\hline Kubau & 0 & 0 & 100 & 0 & 0 & 100 & 0 & 0 & 100 & 0 & 0 & 100 \\
\hline Kudan & 0 & 11 & 89 & 9 & 0 & 91 & 0 & 0 & 100 & 0 & 0 & 100 \\
\hline Makarfi & 0 & 14 & 86 & 0 & 0 & 100 & 0 & 0 & 100 & 0 & 0 & 100 \\
\hline $\begin{array}{l}\text { Sabon/ } \\
\text { Gari }\end{array}$ & 7 & 20 & 73 & 0 & 22 & 78 & 0 & 0 & 100 & 0 & 4 & 96 \\
\hline Soba & 0 & 0 & 100 & 6 & 0 & 94 & 0 & 6 & 94 & 0 & 0 & 100 \\
\hline Zaria & 9 & 9 & 82 & 0 & 38 & 63 & 0 & 12 & 88 & 0 & & \\
\hline
\end{tabular}

missed during polio SIAs [22]. We also found that sustaining some workable interventions beyond polio SIA days (by implementing in-between rounds vaccination) contributed to bridging immunity gaps in the vulnerable communities with records of persistently missed children.

\section{Limitations}

Other interventions were concurrently being implemented during the study period. Some of the improved outcomes demonstrated by this study may be equally attributable to them.

\section{Conclusion}

Scaling up of working innovations in communities with a record of immunity gaps is essential to improving the quality of SIA and interruption of polioviruses in a shorter period hence reducing the long-term cost of additional SIAs.

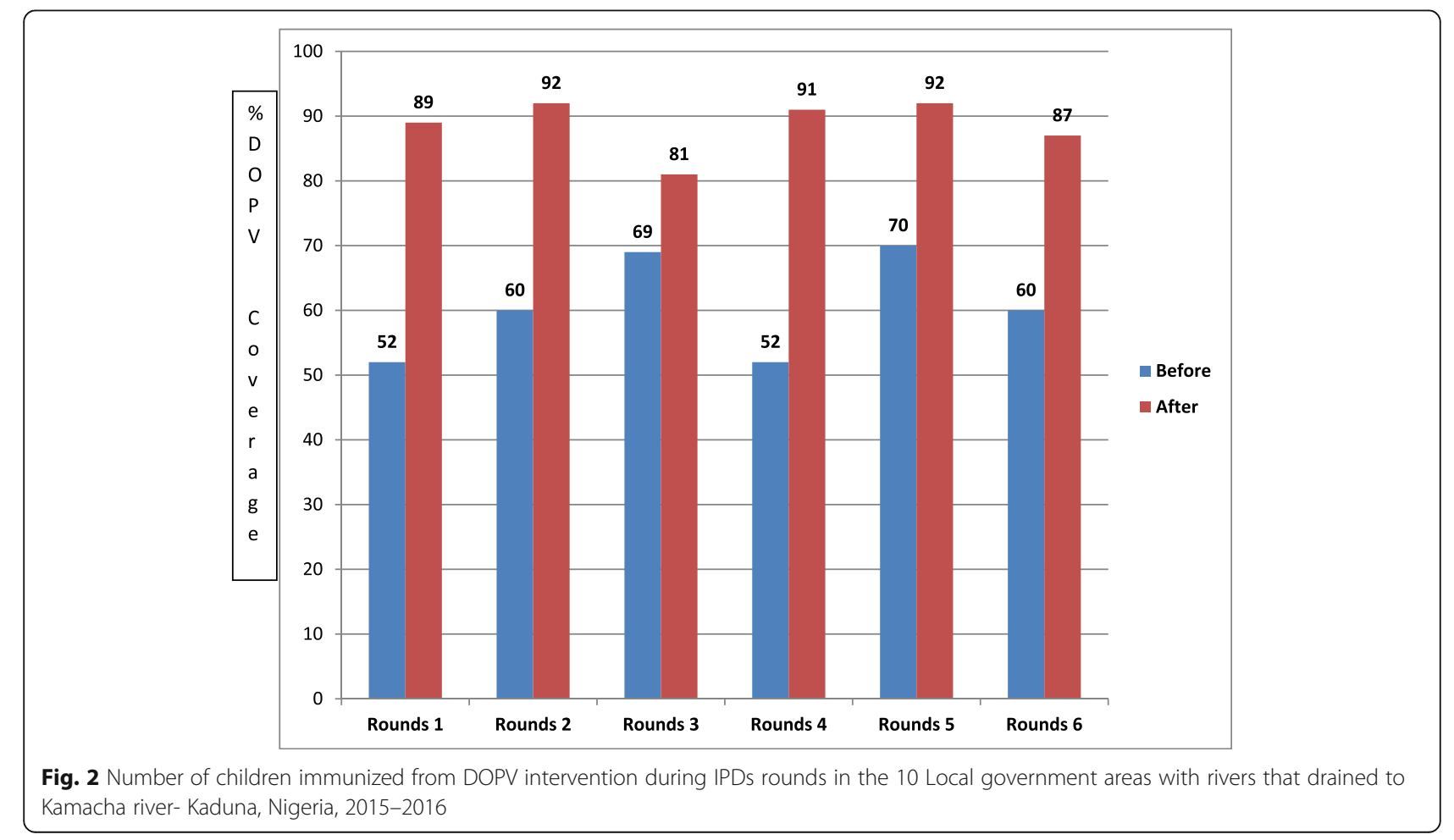




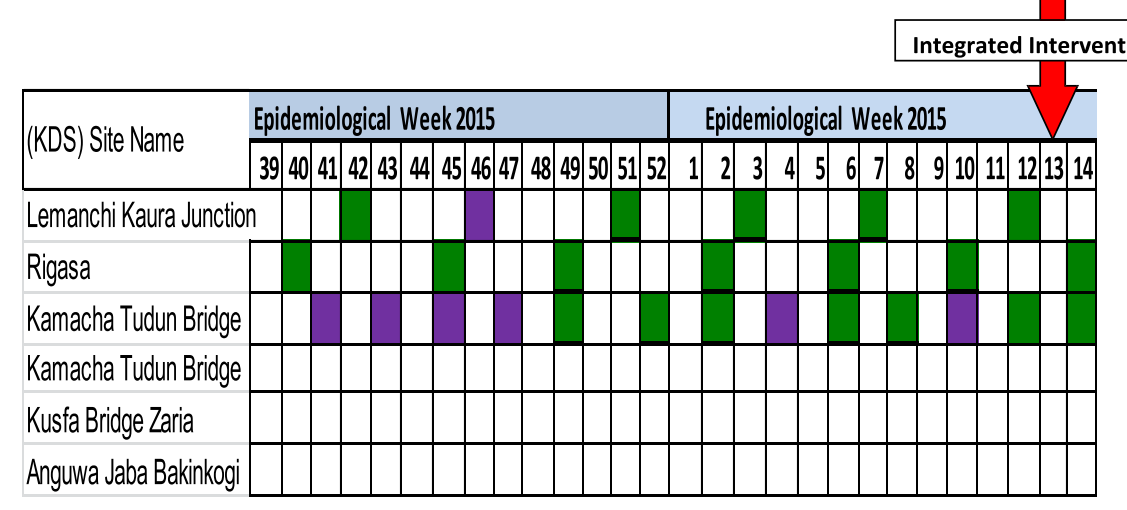

Circulating Vaccine Derived Polio Virus trend before and after the special interventions in the 10 Local government areas with rivers that drained to Kamacha riverKaduna, Nigeria, 2014-2015

NOTE:

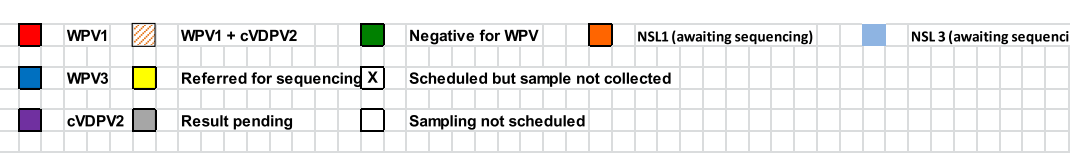

Fig. 3 Circulating Vaccine Derived Polio Virus trend before and after the special interventions in the 10 Local government areas with rivers that drained to Kamacha river- Kaduna, Nigeria, 2014-2015

\section{Recommendations}

We recommend similar interventions in riverine communities with persistent poliovirus transmission. We recommend studies on the cost effectiveness of the scaled-up interventions. These studies should be done in the context of cost per innovations and a potential number of IPDs rounds to be conducted with or without the interventions.

\section{Abbreviations}

cVDPV: Circulatory Vaccine Derived Poliovirus; DOPV: Directly Observed Polio vaccination; DOTS: Directly Observed Short Course; EOC: Emergency Operations Centre; IPDs: Immunization Plus Days; iVDPV: Immunodeficiency Vaccine Derived Poliovirus; LGA: Local Government Area; LQAS: Lots Quality Assurance Sampling; OPV: Oral Polio Vaccine; SAGE: Scientific Advisory Group of Experts; SIAs: Supplemental Immunization Days; VDPV: Vaccine Derived Poliovirus; WHA: World Health Assembly; WHO: World Health Organization

\section{Acknowledgements}

We are grateful to the entire WHO team in Kaduna for their support and efforts in preparing this manuscript. We are also grateful to Lilian Bulage and WHO staff at the country office, whose support and encouragement made this manuscript possible.

\section{Funding}

This work received financial support from WHO country office, Nigeria. Publication of the article was sponsored by WHO grant.

\section{Availability of data and materials}

The tally sheet data of the various rounds of immunization as well as the LQAS, surveillance and laboratory results, were obtained from WHO of which AM, CK, SA, GCU, TIN, HAI, SI, RB and FB were part of. The data supporting the study are available at open repository (datadryad.org.).

\section{About this supplement}

This article has been published as part of BMC Public Health Volume 18 Supplement 4, 2018: Experiences and lessons learned in polio eradication in Nigeria. The full contents of the supplement are available online at https://b mcpublichealth.biomedcentral.com/articles/supplements/volume-18-supplem ent-4.

\section{Authors' contributions}

The study design, methods and data collection were by AM, FS,UA,ED,MB,CK, $S A, G C U, T I N, H A I, S I, R B, P M, R G V, F B$ and PN, while data analysis and discussion were by AM, SGT,CK, SA, GCU, TIN, HAI, SI, RB, FB, PN, VG and HB. All authors read and approved the final manuscript.

\section{Ethics approval and consent to participate}

We obtained ethical approval from the ethical review committee, Kaduna Sate Ministry of Health before the commencement of the various interventions. The vaccination teams obtained consent from mother before administering the vaccines to their children.

\section{Consent for publication}

Our manuscript contains no individual person's data in any form, so no consent was obtained for publication.

\section{Competing interests}

The authors declare that they have no competing interests. 


\section{Publisher's Note}

Springer Nature remains neutral with regard to jurisdictional claims in published maps and institutional affiliations.

\section{Author details}

${ }^{1}$ World Health Organization, Abuja, Nigeria. ${ }^{2}$ National Primary Health Care Agency, Abuja, Nigeria. ${ }^{3}$ Emergency Operations Centre (sEOC), Kaduna, Nigeria. ${ }^{4}$ Kaduna State Primary Health Care Agency, Kaduna, Nigeria. ${ }^{5} \mathrm{Global}$ Public Health Solutions, Atlanta, GA, USA.

Published: 13 December 2018

\section{References}

1. Centers for Disease Control and Prevention (CDC). Progress toward eradication of polio - worldwide, January 2011-march 2013. MMWR Morb mortal Wkly rep. 2013;62(17):335-338 Available from: https://www.cdc.gov/ mmwr/preview/mmwrhtml/mm6217a4.htm. Accessed 15 July 2016.

2. Adams A, Boualam L, Diorditsa S, Gregory C, Jee Y, Mendoza-Aldana J, et al. Maintaining Polio-Free Certification in the World Health Organization Western Pacific Region for Over a Decade. J Infect Dis. 2014;210(suppl 1): S259-S267. Available from: https://doi.org/10.1093/infdis/jiu164. Accessed 15 July 2016.

3. Burns CC, Diop OM, Sutter RW, Kew OM. Vaccine-Derived Polioviruses. Journal of Infectious Disease, 2014;210(Suppl 1):283-293. Available from: https://www.ncbi.nlm.nih.gov/pubmed/25316847 Accessed 15 July 2016.

4. Okonko IO a, Ogun a a B, Adedeji a OC, Akanbi O a D, Udeze a OE, Motayo $\mathrm{OB}$ a F. Circulating vaccine-derived poliovirus and its implications for polio surveillance and eradication in Nigeria: A review of the literature. Sci Res Essays. 2009;4:398-418. Available from: https://www.researchgate.net/ publication/230726666_Circulating_vaccine-derived_poliovirus_and_its_ implications_for_polio_surveillance_and_eradication_in_Nigeria_A_review_ of_the_literature. Accesssed 15 July 2016.

5. Burns CC, Diop OM, Sutter RW, Kew OM. Vaccine-Derived Polioviruses. J Infect Dis. 2014;210(suppl 1):S283-S293. Available from: https://www.ncbi. nlm.nih.gov/pubmed/25316847. Accessed 19 July 2016

6. Polio Eradication and Endgame Strategic Plan Advances Against Polio in 2013-2018. Retrievd, 25 July 2016 Available from: http://polioeradication.org/ wp-content/uploads/2016/07/PEESP_EN_A4.pdf. Accessed 25 July 2016.

7. Johnson Muluh T, Hamisu AW, Craig K, Mkanda P, Andrew E, Adeniji J, et al. Contribution of Environmental Surveillance Toward Interruption of Poliovirus Transmission in Nigeria, 2012-2015. J infect dis . 2016;213 Suppl :S131-S135 Available from: https://www.ncbi.nlm.nih.gov/pubmed/ 26908747. Accessed 25 July 2016.

8. Asghar H, Diop OM, Weldegebriel G, Malik F, Shetty S, El Bassioni L, et al. Environmental Surveillance for Polioviruses in the Global Polio Eradication Initiative. J Infect Dis. 2014;210(suppl 1):S294-S303. Available from: https:// www.ncbi.nlm.nih.gov/pubmed/25316848. Accessed 25 July 2016.

9. Weldegebriel G. Environmental Surveillance for Poliovirus in Polio High Risk States of Nigeria, 2011-2012. Sci J public heal. 2015;3(5):655 Available from: http://www.article.sciencepublishinggroup.com/html/10.11648.j.sjph. 20150305.20.html. Accessed 25 July 2016.

10. Global Polio Eradication Initiative. Annual Report, 2016. Retrived, 25 July 2016 Available from: http://polioeradication.org/wp-content/uploads/2017/ 08/AR2016_EN.pdf. Accessed 25 July 2016.

11. Global Polio Eradication Initiative: Polio Statistics week 24, 2016. Retrieved, 25 July 2016. Available from: http://polioeradication.org/polio-today/polionow/this-week/ Accessed 25 July 2016

12. Global Polio Eradication Initiative: Polio Statistics week 28, 2016. Retrieved, 25 July 2016 Available from: http://polioeradication.org/polio-today/polionow/this-week/. Accessed 25 July 2016.

13. Weiss WM, Winch PJ, Burnham G. Factors associated with missed vaccination during mass immunization campaigns. Journal of Health, Population and Nutrition. 2009;27(3):358-367. Available from: https://www. ncbi.nlm.nih.gov/pubmed/23798696 Accessed 25 July 2016.

14. Cooke J, Tahir F. Polio in Nigeria: The race to eradication. Center Strategic and International Studies. 2012;(February):11-20.Retrieved, 25 July 2016. Available from: https://csis-prod.s3.amazonaws.com/s3fs- public/legacy_files/files/ publication/120210_Cooke_PolioNigeria_Web.pdf Accessed 25 july 2016.

15. Ali D, Banda R, Mohammed A, Adagadzu J, Murele B, Seruyange R, et al. Strengthening Routine Immunization in Areas of Northern Nigeria at High Risk for Polio Transmission During 2012-2014. J infect dis. 2016;213(suppl 3):
S147-S150 Available from: https://www.ncbi.nlm.nih.gov/pubmed/ 26917576. Accessed 25 July 2016.

16. Saint-Victor DS, Omer SB. 15. Vaccine refusal and the endgame: walking the last mile first. Philos Trans R Soc Lond B Biol Sci. 2013;368(1623):20120148. Available from: https:/www.ncbi.nlm.nih.gov/pubmed/23798696. Accessed 25 July 2016.

17. National Primary Health Care Development Agency. 2014 Nigeria polio eradication emergency plan. Res Policy 2014;(December 2013):1-69 Retrieved, 25 July 2016 Available from: http://polioeradication.org/wpcontent/uploads/2016/07/4.2_10IMB.pdf. Accessed 25 July 2016.

18. Warigon C, Mkanda P, Muhammed A, Etsano A, Korir C, Bawa S, et al. Demand Creation for Polio Vaccine in Persistently Poor-Performing Communities of Northern Nigeria: 2013-2014. J infect dis. 2016;213 Suppl: S79-S85. Available from: https://www.ncbi.nlm.nih.gov/pubmed/26908717. Accessed 25 July 2016

19. Shin S, Munoz M, Zeladita J, Slavin S, Caldas A, Sanchez E, et al. How does directly observed therapy work? The mechanisms and impact of a comprehensive directly observed therapy intervention of highly active antiretroviral therapy in Peru. Heal Soc Care Community. 2011;19(3):261-271. Available from: https://www.ncbi.nlm.nih.gov/pubmed/21143333. Accessed 25 July 2016.

20. Michael CA, Ogbuanu IU, Storms a D, Ohuabunwo CJ, Corkum M, Ashenafi S, et al. An Assessment of the Reasons for Oral Poliovirus Vaccine Refusals in Northern Nigeria. J Infect Dis. 2014;210(suppl 1):S125-S130. Available from: https://www. ncbi.nlm.nih.gov/pubmed/25316826. Accessed 25 July 2016.

21. Musa A, Mkanda P, Manneh F, Korir C, Warigon C, Gali E, et al. Youth Group Engagement in Noncompliant Communities During Supplemental Immunization Activities in Kaduna, Nigeria, in 2014. J infect dis. 2016; 213(suppl 3):S91-S95 Available from: https://www.ncbi.nlm.nih.gov/pmc/ articles/PMC4818550/. Accessed 25 July 2016.

22. Gidado SO, Ohuabunwo C, Nguku PM, Ogbuanu IU, Waziri NE, Biya O, et al. Outreach to underserved communities in Northern Nigeria, 2012-2013. J infect dis. 2014;210(Suppl 1):S118-S124 Available from: https://www.ncbi. nlm.nih.gov/pubmed/25316825. Accessed 25 July 2016.

\section{Ready to submit your research? Choose BMC and benefit from:}

- fast, convenient online submission

- thorough peer review by experienced researchers in your field

- rapid publication on acceptance

- support for research data, including large and complex data types

- gold Open Access which fosters wider collaboration and increased citations

- maximum visibility for your research: over $100 \mathrm{M}$ website views per year

At $\mathrm{BMC}$, research is always in progress.

Learn more biomedcentral.com/submissions 